
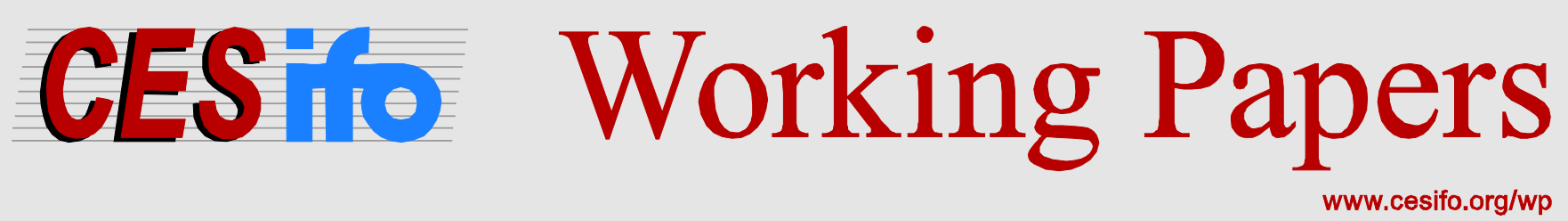

\title{
The Political Economy of Sales Taxes and Sales Tax Exemptions
}

\author{
Andreea Militaru \\ Thomas Stratmann
}

CESIFO WORKING PAPER NO. 5016

CATEgory 2: Public CHOICE

OCTOBER 2014
An electronic version of the paper may be downloaded
- from the SSRN website:
- from the RePEc website:
- from the CESifo website:
www.SSRN.com
www.RePEc.org
www.CESifo-group.org/wp

\section{CESifo}




\title{
The Political Economy of Sales Taxes and Sales Tax Exemptions
}

\begin{abstract}
We analyze the choice politicians face when seeking votes from groups that lobby for sales tax rate decreases or from groups that lobby for certain tax exemptions, given the constraint that politician wants to raise a certain amount of revenue. Using the application of sales taxes and sales tax exemptions we develop a model predicting a positive relationship between the number of sales tax exemptions and the sales tax rate. We find support for the hypothesis that there is an equilibrium relationship between tax rates and exemptions. We find that a one-unit increase in the number of exemptions is associated with an increase between 0.10 and 0.25 percent increase in the sales tax rate.
\end{abstract}

JEL-Code: D720.

Andreea Militaru

Department of Economics

George Mason University

4400 University Drive

USA - 22030 Fairfax VA

militaru.andreea@gmail.com
Thomas Stratmann

Department of Economics

George Mason University

4400 University Drive

USA - 22030 Fairfax VA

tstratma@gmu.edu 


\section{Introduction}

Politicians face conflicting demands from diverse constituent interests. When maximizing their vote share in elections, they attempt to balance these demands. A good example of these conflicting demands concerns taxes. Some constituents want taxes raised on certain groups, while those groups on whom taxes are levied exert pressure to have their taxes lowered. For instance, some groups want high corporate taxes, while corporations prefer low taxes. However, politicians have tools to satisfy both groups, that is, they can support increases in tax rates while also supporting exemptions or loopholes that effectively lower tax rates.

This paper analyzes the practice of balancing sales taxes and sales tax exemptions, given the constraint that politicians want to raise a certain amount of revenue. We study the equilibrium relationship between the sales tax rate and the number of sales tax exemptions in a state. This study is motivated by the theory that those whose taxes are being raised have an incentive to lobby for tax exemptions. Thus, as tax rates rise, so could lobby activities, and so could tax exemptions.

Sales tax revenue can be an important component of a state's total revenues. Its share of the total revenue ranges from zero for states that do not levy a sales tax to 44 percent for states like Washington that rely heavily on sales taxes. For each state, the sales tax revenue is determined by the sales tax rate, the level of economic activity, and the prices of the goods transacted. While sales tax rates are more or less uniform among states, the goods and services exempted from taxation and the administration of sales taxes vary greatly from state to state.

For this study, we compiled an inventory of all sales tax exemptions for all the states that levy a sales tax, together with an extensive background on how the states implement sales tax exemptions. This inventory is the starting point for a quantitative analysis of the impact of sales 
tax exemptions on sales tax rates and revenues across states. We show that there is a positive and statistically significant relationship between sales tax rates and sales tax exemptions, which is consistent with our theoretical model.

The next section introduces the conceptual framework for analyzing the relationship between sales tax rates and sales tax exemptions. The third section provides background on the variety of sales tax rates as well as the types of sales tax exemptions across states. The fourth section describes the methodology we used to collect and classify the sales tax exemptions data. The fifth section presents the data analysis, and we conclude in the final section.

\section{Previous Work and Conceptual Framework}

The literature on the interconnectedness of sales tax rates and sales tax exemptions is not large. Some of the research focuses on the impact of nonprofit sales tax exemptions on the allocation of resources between the nonprofit and the for-profit sectors (Hansmann 1987). Other work analyzes the effectiveness of certain business tax incentive programs for increasing business activity in a state (Hall 1999, Ihlanfeldt 1995). Other tax studies test predictions of sales tax models (Besley and Rosen 1998), elasticities (Bruce et al. 2006, Hawkins 2002), and the effectiveness of taxes to improve health, including taxes on soda or sugar(Powell and Chaloupka 2009, Brownell et al. 2009, Chouinard et al. 2006).

The conceptual model we use to understand taxes and exemptions borrows from Peltzman (1976), who has analyzed how politicians regulate firms, given that firms demand regulations that increase their supply prices and consumers demand regulations that lower prices.

In our model, a politician competes for the votes of two groups: one group that prefers decreases in the tax, and another group, that prefers increases in tax exemptions. Given a revenue 
constraint, the politicians cannot please both groups. When the politician decreases taxes thereby increasing support from one group, he or she will lose support from the other group because the revenue constraint forces him or her to decrease tax exemptions. Similarly, when increasing exemptions, the politicians has to increase taxes to keep revenues raised constant. The politician is therefore faced with choosing a tax rate and a variety of exemptions that can maximize his or her chances of re-election. However, as noted, in maximizing the chances of reelection, the politician faces the difficulty that the wealth of one interest group can increase only at the expense of another group.

Figure 1 illustrates this situation. The politician picks a policy that offers the best mix of sales taxes and exemptions that maximizes the chances of reelection. This equilibrium is constrained by a predetermined revenue goal and the politician’s support function, which increases in higher exemptions and lower taxes.

Assuming that all states raise a similar amount of revenue per capita, the revenue constraint shows all possible equilibrium combinations between tax rates and exemptions. With these assumptions, the model predicts a positive correlation between sales tax rates and exemptions. Thus in our empirical model we will test for the equilibrium relationship between exemptions and tax rates.

\section{Variations in Sales Taxes and Exemptions across the United States}

\section{A. Sales Taxes and Tax Bases}

Of the 50 states, only Alaska, Delaware, Montana, New Hampshire, and Oregon do not have a statewide sales tax. Among the remaining states, sales taxes differ primarily in name and in the transactions covered by the tax, that is, the tax base. Sales tax exemptions also differ across 
states. The term sales tax base refers to the variety of transactions for which a sales tax is levied. States can opt for a wide sales tax base and a low sales tax rate, or for a narrow sales tax base but a high sales tax rate. Both options can achieve the same amount of tax revenue.

With respect to the name of the sales tax, in some states—for example, Arizona-the legal language for a sales tax is a "transaction privilege tax," which is a tax that applies to retail sales. The Arizona statute describes this tax as a tax on the vendor for the "privilege of doing business in Arizona” (Arizona Code Title 42, Chapter 5, Article 1). For other states—for example, Arkansas, Kansas, and New Mexico-the legal language refers to the sales tax as a "gross receipts tax," which is levied on all sales of tangible personal property, not on the property itself (Arkansas Rules, Gross Receipts Rules, GR-5). “Gross receipts” means the same as "gross proceeds" or the "sales price.” For example, gross receipts in Arkansas are "the total amount of consideration, including cash, credit, property, and services, for which tangible personal property or services are sold, leased, or rented, valued in money, whether received in money or otherwise” (Arkansas Code Title 26, Chapter 52, Subchapter 1).

With respect to the tax base, most states define the tax base broadly in statements such as "sales tax is a privilege tax imposed on the retail sale of tangible personal property sold in the state of. ...” (Alabama Code, Title 40, Chapter 23, Article 1). Tangible personal property tends to cover a wide range of goods and services that can be measured, hence the reference to "tangible." The definition of tangible personal property is the most important determinant of the sales tax base. Since each state has a specific definition of tangible personal property, sales taxes across states differ with respect to the type of sales they apply to: retail sales, rentals, leases, etc. For example, Arkansas levies a gross receipts tax and defines gross receipts as "all the gross 
proceeds derived from all sales of tangible personal property, certain services and admission fees” (Arkansas Rules, Gross Receipts Rules, GR-4).

However, states use discretion in choosing when to apply a sales tax to other nonretail transactions. Illinois, for example, refers to sales taxes as a combination of occupation taxes that are imposed on sellers' receipts, and use taxes that are imposed on amounts paid by buyers, that is, the consumers of the goods and services. As a result, Illinois sales taxes encompass a number of types of state and local taxes, both of which include the classic sales taxes imposed in many other states: mass transit taxes, water commission taxes, and home rule occupation taxes. They also include use taxes, park district taxes, county public safety and facilities taxes, county school facility taxes, and business district taxes. Illinois is a unique case, where the sales tax incorporates a variety of separate local excise taxes. For the purposes of our paper, we only include Illinois's state sales taxes; local and county sales taxes that may be in addition to the statewide tax are excluded.

\section{B. A Taxonomy of Sales Tax Exemptions}

B.1. Federal preemption. Sales tax exemptions cover various categories of transactions that are not subject to the sales tax. Similar to sales tax bases, exemptions from sales taxes also vary across states. However, some legal exemptions apply to all states. Under the principle of federal preemption, certain federal laws prevent all states from charging sales taxes on a number of transactions. Those include purchases made by foreign diplomats, certain transactions made on federal Indian reservations, interstate commerce transactions, transactions involving instrumentalities of the United States, purchases by federal credit unions, and transactions covered by federal food assistance programs. 
The Commerce Clause of the US Constitution gives Congress the power "to regulate commerce with foreign nations, and among the several states, and with the Indian tribes.” Pursuant to this clause, the US government grants immunity from state sales taxes to diplomats from certain countries. For this purpose, the US Department of State issues a federal tax exemption card (with a federal tax exemption number) as proof of exempt status. Further, Native Americans are exempt from paying sales taxes on any transaction made on a federal Indian reservation. But transactions made on "allotted” lands, "restricted status" lands, and state Indian reservations are not covered by this federal mandate; however, they could still be exempt under a state’s sales tax law.

And finally, according to the Commerce Clause, states are prevented from taxing interstate commerce transactions. (Most states will require a seller to retain documentary evidence of making a valid sale in interstate commerce.) This type of exemption includes all retail transactions that involve goods delivered to a common carrier for transportation out of state, or to an independent transportation business hired by the seller. Additionally, transportation assets used in interstate commerce, such as locomotives, aircraft, and repair parts, and vessels and maritime supplies are also exempt. Regarding vessels and watercraft, the National Maritime Transportation Security Act of 2002 prohibits states from imposing taxes on any vessel or watercraft, or the passengers or crew of a vessel or watercraft.

States are prevented from charging sales taxes on purchases and sales made by federal agencies and other US instrumentalities, such as the American Red Cross. Further, purchases made by federal credit unions are exempt according the United States Code. ${ }^{1}$

\footnotetext{
${ }^{1}$ United States Code, 2006 Edition, Supplement 5, Title 12 - BANKS AND BANKING. Title 12 - BANKS AND BANKING CHAPTER 14 - FEDERAL CREDIT UNIONS, SUBCHAPTER I - GENERAL PROVISIONS, Sec. 1768 - Taxation
} 
Purchases of eligible food items with coupons issued under the Federal Food Stamp Program (currently known as the Supplemental Nutrition Assistance Program), which is administered by the US Department of Agriculture, are exempt from sales tax in any state. Also, exempt are purchases made using food checks issued by the federal Special Supplemental Food Program for Women, Infants, and Children (WIC).

B.2. State sales taxes: types and special exemptions. The states have the discretion whether to grant sales tax exemptions for any transactions that are not already governed by federal preemption laws. Based on various criteria, one can develop different ways to categorize discretionary sales tax exemptions across states: transaction-based, implementation-based, taxrate, and policy-based exemptions. As such categories are not mutually exclusive, an exemption can fall under multiple categories; therefore care has to be applied when using e any categories to understand the variety of sales tax exemptions. We show a summary of these exemption categories in table 1.

B.2.1. Transaction-based exemptions. These include the key economic transactions that are exempt from sales taxes. We further divide the transaction-based exemptions into three subcategories: entity-based, product-based, and use-based exemptions.

Entity-based exemptions are based on the seller or buyer being an exempt entity. This category includes most exemptions linked to nonprofit organizations, schools, and certain manufacturers and agricultural producers. 
Product-based exemptions are based on the items sold or purchased, regardless of the type of buyers or sellers involved in the transaction. For example, this category often includes food or health-related items.

Use-based exemptions are based on the buyers' intended use of the items being transacted. Examples in this category are exemptions for electricity for residential use and certain materials or tools used in a manufacturing process or in an agricultural production process.

While these three transaction-based categories seem fairly straightforward, they are not mutually exclusive since one exemption can satisfy multiple criteria. An example would be "sales of food to students in school cafeteria or lunchrooms," which is a common exemption among most states. Such an exemption could be categorized as product-based, since it involves a commonly exempted good, namely food, but it could also be categorized as an entity-based exemption, as it involves a commonly exempted entity, namely schools. This example shows that exemptions categories can be useful points of reference when navigating through the tax codesimportant caveats to keep in mind.

B.2.2. Implementation-based exemptions. This category is based on the way exemptions are claimed by buyers and on the details regarding their implementation. There are two subcategories of exemptions: The first are applied automatically and the second require approval or need proof in order to be claimed. The latter subcategory highlights the degree of effort that has to be expended for sales tax exemption rules and laws to translate into tax savings.

With automatic exemptions, neither the buyer nor the seller is required to present or retain proof that the transaction is exempt. The most common automatic exemptions involve food and health-related items. West Virginia is one the only state that differentiate automatic exemptions_-which they label "per se” exemptions—-from non-automatic exemptions. Per se 
exemptions in West Virginia include health-related items; sales of publicly regulated utilities (steam and water); tuition and room-and-board charges made by educational organizations; fundraising transactions involving churches and certain nonprofit organizations; etc. West Virginia's accounting of exemptions allows for easy categorization. For all of the other states, it can be time consuming to determine whether an exemption is automatic or not, often requiring in-depth research.

Approval-based exemptions generally require pre-approval from a state’s Department of Revenue, or they require the seller or buyer to use and retain proof that a transaction qualifies as exempt. The most common form of proof is a certificate of exemption, which is an official form that a seller or buyer fills out to show proof for claiming an exemption. These forms can exempt a specific transaction or a specific buyer (various nonprofit organizations), or they can exempt the specific use of a product (certain equipment to be used on farms). These certificates can be paper forms that are to be presented when making a purchase, or they can be electronic certificates. Maryland, for example, assigns a certificate number for each certificate issued and allows sellers to check the validity of the certificate online.

B.2.3. Tax-rate category. This category focuses on the effective sales tax rate applied to a transaction. Exemptions fall under two subcategories: full or partial exemptions. Full exemptions are transactions that are not subject to any sales tax. Partial exemptions include transactions that are taxed at a lower rate than the general sales tax or transactions for which the general sales tax rate is only applied to a percentage of the gross proceeds from a retail sale. Virginia, for example, taxes food items at a 1.5 percent rate, while the general sales tax rate is 4 percent. Utah 
and Vermont apply the general sales tax to only 60 percent of the price of a new modular home, leaving 40 percent exempt.

B.2.4. Policy-Based Exemptions. These refer to exemptions that are a result of various policies. Such exemptions can be organized in four subcategories.

The first subcategory of policy-based exemptions are those that aim to have a social impact, meaning they are intended to protect certain groups or certain activities within society. Examples of such exemptions include all food and health-care-related exemptions.

The second policy-based subcategory of sales tax exemptions are exemptions from the sales tax base that are not necessarily meant to have a defined social impact. These exemptions occur whenever a state defines the type of transactions that are subject to sales taxes. For example, such exemptions involve transactions with “intangible” personal property, which can be defined differently in each state. Transactions that are covered by certain federal laws that prevent states from taxing them can also fall under this category.

The third category of policy-based exemptions refers to transactions that are exempt mainly because it can be too costly for the state to tax them relative to the revenue it would get. This category includes exemptions for casual or isolated sales namely small-scale transactions that are not performed on a regular basis or by a retailer-garage sales, flea market sales, or even sales of business assets between related companies.

The fourth category of policy-based exemptions involves transactions that some states include under the sales tax base while other states apply a different tax. These transactions are generally industry-related. For example, depending on the state, tourism transactions can either fall under the sales tax or under more specific taxes (hotel occupancy tax, resort taxes, etc.). 
Further, some states, such as Rhode Island, define alternative taxes that only apply to such specific transactions.

B.2.5. Special exemptions. The sales tax holiday is a special type of exemption that has been adopted in 17 states. During a specific time period, certain items are not subject to any sales tax, even though they generally are taxable outside of that time period. The most common type is the Back to School tax holiday, which generally takes place in August and exempts certain clothing and school-related items. Another type is the Energy Star tax holiday, when for a limited amount of time, consumers can purchase certain energy-efficient household appliances tax-free. Virginia also has a sales tax holiday every May that exempts certain hurricane and emergency-preparedness equipment. These special exemptions can be categorized as a partial exemption, given that only certain goods and transactions are exempt from sales taxes for a limited amount of time. However, one could also categorize them as exemptions with a social impact, given that the exemptions aim to encourage certain types of economic activities or the purchase of certain goods.

\section{Collecting and Categorizing the Data}

\section{A. Data Sources}

No unified, systematic source provides the number and types of sales tax exemptions in each state. Therefore, we collected sales tax exemptions from all the states that levy a sales tax by accessing a variety of sources. These sources include state sales tax codes, sales tax rules and regulations, and information briefs or reports published on each state's Department of Revenue 
web page. To arrive at this comprehensive inventory of exemptions, we consulted over 8,800 pages of information.

Sales tax codes are legal documents that provide the general framework for enacting a sales tax. These sources provide an initial understanding of how each state defines its tax base and the exempt transactions. However, they are not standardized across states and do not include all sales tax exemptions. Sales tax rules and regulations are generally complementary to sales tax codes; they represent each state's effort to clarify the circumstances under which sections of the sales tax codes are applied or not applied. Thus, they provide useful information as to which transactions are exempt from sales taxes.

Further, we reviewed publications listed on each state’s Department of Revenue website that provide information regarding the latest changes in exemptions and tax rates, as well as information regarding the forms required to claim certain exemptions. Among all the states, only five (California, Iowa, Louisiana, New York, and Washington) keep an updated comprehensive list of the sales tax exemptions in their state. Tax specialists from the Department of Revenue of many of the other states assisted us in identifying the appropriate sales tax rules and regulations that identified exemptions.

Another source of information for this paper was the Streamlined Sales Tax (SST) Project, a unique attempt to standardize and harmonize definitions of goods and transactions for sales tax purposes. The National Governor's Association (NGA) and the National Conference of State Legislatures (NCSL) initiated this project in 1999, responding to two Supreme Court decisions: Bellas Hess v. Illinois and Quill Corp v. North Dakota. In both cases, the court had ruled that a state could not require a seller who does not have a physical presence in the state to collect taxes on sales for that state. The court noted that one reason for their decision was that 
imposing sales tax collection on a business without a physical presence is too complicated under the current sales tax system. To address this difficulty, the SST Project created the Streamlined Sales and Use Tax Agreement. This agreement aims to simplify sales tax administration and certain sales tax exemptions by adopting uniform standards and definitions. Twenty-four states have adopted this agreement. ${ }^{2}$

Each of the participating states generates a State Taxability Matrix form that records the state's sales tax coverage for certain standardized categories of transactions. The forms include three major sections: Administrative Definitions, "State Tax Holidays, and Product Definitions for ten categories of products. These categories are clothing and related products, computerrelated products, mandatory computer software maintenance contracts, optional computer software maintenance contracts, digital products, food and food products, prepared food options, health-care products (drugs, durable medical equipment, mobility-enhancing equipment, prosthetic devices), telecommunications, and telecommunications-related products. For each category in the State Taxability Matrix, a state lists whether a product or transaction is taxed or is exempt and also lists the relevant section of the sales tax code that covers the product or transaction. However, while the taxability matrix forms were helpful from a data collection perspective, they only record information on a fraction of the transactions and products that a state exempts, and currently only the 24 states who are members of the SST project are filling out these forms each year.

Our data for sales tax rates are from 2012, whereas sales tax revenue, GDP information, and resident population estimates for each state are from 2009, as published by the US Census

\footnotetext{
${ }^{2}$ These states include Arkansas, Georgia, Indiana, Iowa, Kansas, Kentucky, Michigan, Minnesota, Nebraska, Nevada, New Jersey, North Carolina, North Dakota, Ohio, Oklahoma, Rhode Island, South Dakota, Tennessee, Utah, Vermont, Washington, West Virginia, Wisconsin, and Wyoming.
} 
Bureau. Further, we obtained 2010 data on the local option taxes. States that have a local option in their statues allow some legal entities within their states, such as cities or counties, to levy a tax on a good, in addition to the statewide sales tax. Moreover, obtained information about each state's sales tax exemptions from the latest updates of state publications, the dates of which ranged from 2008 to 2012. The SST taxability matrix forms are from of 2011.

Our inventory of sales tax exemptions focuses on identifying transactions and goods that are exempt from sales tax. As such, it does not include details on how to claim the exemptions or any other legal background for them.

\section{B. Building Exemption Categories}

As mentioned previously, sales tax exemptions can be categorized according to a variety of criteria, and states do not have common definitions for exempt products, services, or transactions. In order to conduct a statistical analysis, we needed to develop standardized exemption categories that would provide some degree of accuracy in counting sales tax exemptions.

A limitation of our categories classification is that they cannot account for many variations in exemptions. For example, in some states "food products" refers to unprocessed food ingredients only. In other states "food products" also includes, candy, soda, dietary supplements, or baked goods. Therefore, while many states exempt food products, the actual products exempted will not always be the same.

We developed two criteria that have to be met for building categories of exemptions. First, the categories have to be specific enough that exemptions cannot be placed in multiple 
categories. Second, the categories have to be broad enough to accommodate a wide variety of definitions that states may have for products or transactions.

We categorize exemptions according to the economic area to which they are applied. This approach is similar to the transaction-based exemptions, which are categorized as entity-based, product-based, or use-based.

We identified 17 broad economic exemption categories. Each category includes a variety of exemptions that can be categorized as entity-based, product-based, use-based, or as either partial or full exemptions. The 17 categories are Food, Health, Clothing, Transportation, Housing, Capital Goods/Industry, Computer, Energy/Utilities, Farming/Agriculture, Business Incentives, School- Related, Nonprofits, Government-Related, Entertainment, Services, Tax Holidays, and Other. Clearly, developing these categories and assigning exemptions to them involve many judgment calls. Table 2 provides a description of our 17 categories.

One important guide we consulted in developing these categories was a publication by California’s State Board of Equalization (Publication no. 61 “Sales and Use Taxes: Exemptions and Exclusions California Revenue and Taxation Code Part 1, Division 2”, published in February 2012), which listed sales tax exemptions in California. However, our categories are not identical to those in the California publication. We modified them to reflect the type of goods, transactions, and entities related to the sales tax exemptions.

\section{Caveats and Subcategories}

We did not count exemptions based simply on how many were listed in a state's tax code. Some states have detailed and very specific conditions as to the types of goods or services that are exempt and when and how exemptions apply. Other states have a few broad and generic 
exemptions. For example, Massachusetts exempts “materials, tools, machinery and replacement parts that will be used directly and exclusively in the actual manufacture, processing or conversion of tangible personal property to be sold, including the publishing of a newspaper or the operation of commercial radio broadcasting or television transmission” (Massachusetts General Laws, Part I Administration of the Government, Title IX Taxation, Chapter 64H Tax on Retail Sales of Certain Tangible Personal Property, Section 6S Exemptions), In contrast, Colorado exempts machinery and tools for manufacturing under very specific conditions. Namely that they be used in Colorado; be used directly and predominantly to manufacture tangible personal property for sale or profit; be of a nature that would have qualified for the federal investment tax credit under the definition of section 38 property found in the IRS Code of 1954 , as amended; be included on a purchase order or invoice totaling more than $\$ 500$; be capitalized, etc. (C.R.S. 39-206-709.1). Moreover, states can have very narrow or particular definitions for categories of goods. Here, classifying exemptions into categories involves many judgment calls. One example is how states define food products exemptions. Some states exempt only general unprepared grocery items, others also exempt items like candy, soda, bubble gum, bakery items, dietary supplements, etc.

Consequently, a comparison between such exemptions is challenging. For simplicity and accuracy, we developed exemption subcategories within our 17 main categories. When a state had any exemption that fell within a specific subcategory, we assigned a value of one to that subcategory. Each of our main categories has up to 6 subcategories. In total, there are $\mathrm{f} 30$ categories and subcategories, as shown in table 2. 
For our analysis, we include only exemptions when they were fully applied to the sales tax by the states. That is, we include an exemption only when the general sales tax rate was not applied to a good, service or transaction. We do not consider partial exemptions.

Some states have one standard form that is can be used by either party (buyer or seller) of a tax-exempt transaction as proof for not paying (buyer) or collecting (seller) sales tax. Other states choose to use transaction-specific forms that cover only a specific type of transactions. Therefore, while the number of exemption forms a state uses is not a direct indication of the ease with which one can claim an exemption, it provides another differentiation in terms of implementing sales tax exemptions.

\section{Descriptive Statistics and Estimation Results}

The theoretical model assumes that politicians can choose any sales tax rate and exemptions combination that meets a revenue constraint. However, in some states politicians cannot set the sales tax rate because they are constrained by either the constitution or referenda. As previously mentioned, five states do not have a sales tax because it is not part of their constitution; we have therefore omitted these states from our study. In Colorado, which is included in our study, voters passed a referendum that does not allow politicians to increase the sales tax rate.

We have also omitted Hawaii from our analysis. Hawaii’s sales tax is a three-tiered general excise tax that is assessed on all business activities: 0.15 percent for insurance commission; 0.5 percent for wholesaling, manufacturing, producing and wholesale services, imports for resale; and 4 percent for all others. ${ }^{3}$ Furthermore, Hawaii has no exemptions of any

\footnotetext{
${ }^{3}$ Tax Facts 96-1, General Excise vs. Sales Tax http://www6.hawaii.gov/tax/taxfacts/tf96-01.pdf
} 
kind for its excise tax. Since Hawaii has a multi-tiered sales tax rate, choosing a tax rate for our data set would be arbitrary and therefore we have excluded Hawaii from the analysis.

We estimate the regression model:

Sales Tax Rate ${ }_{i}=\beta_{1}+\beta_{2}$ Exemption $_{i}+\beta_{3}$ SalesTaxRevPC $_{i}+\beta_{4}$ TaxBase $_{i}+\varepsilon_{i}$.

In this regression, the unit of observation is state $i$. We control for sales tax revenue per capita because the theoretical model suggests that the politician picks the sales tax-exemption combination, subject to a revenue constraint. By including this variable, we account for the constraint. A further constraint is the tax base. A narrow tax base may force a different trade-off in setting the sales tax rate and exemptions than a broader tax base. To compute the measure for the tax base, we consulted the state laws and regulations regarding sales taxes and assigned to each state a value between one and five, where five indicates the broadest tax base.

For total exemptions we have two measures: The first measure is based on our main 17 exemption categories and the various subcategories (table 2). The second measure collapses all the subcategories within each exemption category and merges two categories—governmentrelated and nonprofits—-to create a new category, exempt organizations. Both nonprofits and government agencies have a sales tax-exempt status in light of their organization status. Thus, by grouping them into one broader category of exempt organizations, we capture all sales tax exemptions related to organizations. This specification further simplifies the breakdown of exemptions and narrows the number of categories to 16 .

Our first measure of exemptions is a count of the sum of full exemptions from all exemption subcategories within the 17 main categories of exemptions. When a main category 
does not have a subcategory, and the state is coded as having exemptions in that main category, we add one to the count. The range of this exemption count among the states is 19 to 31, with an average number of exemptions of 24.2 (see table 3).

Our second measure consists of an exemption count based on our main 17 categories. If a state has exemptions in more than half of the subcategories, we assign a value of 1.0 to that main category. Conversely, we code the main category as 0.0 if it has exemptions in less than 30 percent of the subcategories, and assign a value of 0.5 if that main category has more than 30 percent of the exemptions but less than half. We then sum the values assigned to each category. For this second measure the mean number of exemptions is 11.4 and the range of this variable is between 7 and 14.5 (table 3).

Table 3 also shows summary statistics for our other variables. The mean sales tax across the 44 states is 5.6 percent, ranging from 2.9 percent to 7.25 percent. Sales tax revenue per capita from 2009 averages at about $\$ 778$ per state and ranges between $\$ 421$ to $\$ 1,756$. The tax base values range between 1 and 5 .

Table 4 shows the regression results when we use our broad exemption measure. The first column includes exemptions, sales taxes per capita and sales taxes per capita squared, to allow for non-linearities, in the regression. The second column adds indicators for the various tax bases. Column 3 and column 4 re-estimate the first two specifications, but replace the level and square of sales taxes per capita with the log of sales taxes per capita. In columns 5 to8, we show that our results for columns 1-4 are robust when also controlling for local options. In all eight specifications, the point estimates on the exemption measure in the sales tax rate regression are positive and statistically significant, lending support to our hypothesis. The point estimates indicate that one additional exemption is associated with an increase in the sales tax rate by 
between 0.10 and 0.15 percentage points. The last four columns show that when controlling for local option law, results levels of statistical significance slightly improve, further lending support to our initial hypothesis.

As for our control variables, as one might expect, log sales tax revenues are positively correlated with sales tax rates. And the first two specifications, with the level and the square of sales tax revenue as covariates in the regression, support the finding that sales taxes are positively correlated with sales tax revenues but also that this correlation is weaker at higher revenue levels. Finally, as expected, local options are negatively correlated with sales tax rates, although this relation is statistically significant for columns 5 and 6 only.

The reference group for our tax base indicators in all columns in table 4 is states with the narrowest sales tax base. The point estimates on all but the third tax base category are positive and statistically significant. And with the exception of this third category, the coefficients are larger in magnitude as the tax base broadens.

The finding that sales taxes tend to be higher when the tax base is higher is somewhat surprising. This is because broader bases allow for lower taxes while holding revenue constant.

Figure 2 shows the partial regression plot between the sales tax rate and sales tax exemptions. The graph includes the data points and the regression line, showing the positive correlation between these two variables. Further, this positive correlation is not just evident in a couple of states; it is a pattern throughout the data.

Table 5 shows the results from re-estimating the specifications in table 4, but now using the narrower measure of exemptions. Because the range of the exemption variable decreases, we expect that the point estimates on this exemption variable will be less precisely estimated.

Further, given these categories are narrower than the exemption categories in table 4, we expect 
that the point estimates in table 5 on the exemption measure are larger than the corresponding point estimates in table 4.

The findings in table 5 broadly support our hypothesis. As with the previous measure (see table 4) all point estimates across the eight regression equations on the exemption measure are positive. The estimates for the exemption measure that include the tax base indicators are statsticially significant at the 5 percent level (table 5, columns 2 and 4), and the other two estimates (table 5, columns 1and 3) barely miss the 10 percent level of significance. Controlling for local options still leaves two estimates (table 5, columns 5 and 7) short of the 10 percent level of significance. The reduction in the level of statistical significance was expected, given that the regressions now use the narrower exemption variables, which have less variance. The point estimates on the control variables have the same signs and similar levels of significance as those in table 4, thus supporting the previous findings that higher sales tax rates are positively correlated with the per capita sales tax revenues and the broadness of the tax base.

Figure 3 shows the partial regression plot for the narrow specification of table 5 . As in the previous partial regression plot (figure2), there is a clear positive pattern between sales tax exemptions and sales tax rates.

To reinforce our findings and not reported in this paper, we performed several robustness tests to further examine our hypothesis regarding an equilibrium relationship between sales tax rates and exemptions. First, we added a regional control variable to our models in order to account for cross-influence between neighboring states in regards to sales tax rates or exemptions. Second, we controlled for state income tax revenue per capita to see how this impacts the relationship between tax rates and exemptions. Finally, we re-tested the equations 
using the least absolute deviations method. All of these alternative specifications supported our reported findings.

\section{Conclusions and Policy Implications}

This paper shows that there is a positive relationship between the number of sales tax exemptions and the sales tax rate across the states. We find that a one-unit increase in the number of exemptions is associated with a 0.10 to 0.15 percent increase in the sales tax rate for our broad measure of exemptions, and with a 0.14 to 0.25 percent increase for our narrow measure of exemptions. This magnitude indicates that one additional exemption is associated with an increase between $9(0.10 / 1.1)$ and $13(0.15 / 1.1)$ percent of the standard deviation in tax rates. This means, adding another sales tax exemption leads to an increase in the sales tax rate ranging from 0.10 percent to 0.25 percent. Thus, if a state currently has a sales tax rate of 5 percent and the state decides to add another sales tax exemption (as defined in previous sections), then this is equivalent to increasing the state's sales tax rate from 5 percent to between 5.1 percent and 5.25 percent

High tax rates increase the incentive to lobby for special exemptions. When accompanied by exemptions, higher tax rates do not necessarily lead to higher tax revenues. Our evidence that higher tax rates are associated with more tax exemptions provides one explanation as to why estimates of revenue increases generated by sales tax increases are often too optimistic. Therefore, agencies estimating the effect of a sales tax rate increase on tax revenues should take into account the likelihood that higher sales tax rates will lead to an increase in the number of sales tax exemptions, which in turn will lower sales tax revenues. 


\section{References}

Besley, T. J., \& Rosen, H. S. (1998). Sales Taxes and Prices: An Empirical Analysis. NBER Working Paper No. 6667. National Bureau of Economic Research.

Brownell, K. D., Farley, T., Willett, W. C., Popkin, B. M., Chaloupka, F. J., Thompson, J. W., \& Ludwig, D. S. (2009). The Public Health and Economic Benefits of Taxing SugarSweetened Beverages. The New England Journal of Medicine 361(16), 1599-1605.

Bruce, D., Fox, W. F., \& Tuttle, M. (2006). Tax Base Elasticities: A Multi-State Analysis of Long-Run and Short-Run Dynamics. Southern Economic Journal, 73(2) 315-41.

Chouinard, H. H., Davis, D. E., LaFrance, J. T., \& Perloff, J. M. (2006). Fat Taxes: Big Money for Small Change. Working Paper No. 1007. Department of Agricultural and Resource Economics and Policy, University of California at Berkeley.

Hall, B. H. (1999). Effectiveness of the California R\&D Credit. California Council on Science and Technology. http://www.ccst.us/publications/1999/CREST4.pdf

Hansmann, H. (1987). The Effect of Tax Exemption and Other Factors on the Market Share of Non-profit versus For-profit Firms. National Tax Journal vol 40, 71-82.

Hawkins, R. R. (2002). Popular Substitution Effects: Excess Burden Estimates for General Sales Taxes. National Tax Journal 55(4). 755-770.

Ihlanfeldt, K. R. (1995). Ten Principles for State Tax Incentives. Economic Development Quarterly,vol 15, 339-55.

Peltzman, S. (1976). Toward a More General Theory of Regulation. Journal of Law and Economics, 19: 211-40.

Powell, L. M., \& Chaloupka, F. J. (2009). Food Prices and Obesity: Evidence and Policy Implications for Taxes and Subsidies. The Milbank Quarterly, 87(1), 229-57. 


\section{Data Sources}

Alabama Revenue (2012). Sales and Use Taxes FAQ, retrieved from http://www.revenue.alabama.gov/salestax/faq.html\#8

Alabama Revenue (2012). Rules Numeric Index, retrieved from http://www.ador.state.al.us/salestax/Rules/numindex.html

Arizona Revenue (2011). Summary of Arizona Taxes, retrieved from http://www.azdor.gov/LinkClick.aspx?fileticket=8mo41E3QChg\%3d\&tabid=85

Arizona Revenue (2011). The Revenue Impact of Arizona’s Tax Expenditures FY11, retrieved from

http://www.azdor.gov/LinkClick.aspx?fileticket=WQJo4tyBtcU\%3d\&tabid=108\&mid=4 92 (pp. 97).

Arizona Revenue (2012). Transaction Privilege Tax, retrieved from http://www.azdor.gov/Business/TransactionPrivilegeTax.aspx

Arkansas Finance (2008). Arkansas Rules, retrieved from http://www.dfa.arkansas.gov/offices/policyAndLegal/Documents/et2008_3.pdf

Arkansas Finance (2011). What's New for Sales Tax in 2011, retrieved from http://www.dfa.arkansas.gov/offices/exciseTax/salesanduse/Documents/whatsnew2011.p df

Arkansas Finance (2012). Sales and Use Tax, retrieved from http://www.dfa.arkansas.gov/offices/exciseTax/salesanduse/Pages/Co.aspx

California Board of Equalization (2012). California City and County Sales and Use Tax Rates, retrieved from http://www.boe.ca.gov/sutax/pam71.htm

California Board of Equalization (2012). Sales and Use Taxes: Exemptions and Exclusions, retrieved from http://www.boe.ca.gov/pdf/pub61.pdf

California Board of Equalization (2012). Certificates Used in Sales \& Use Tax Regulations, retrieved from http://boe.ca.gov/sutax/certforms.htm

Colorado Revenue (2012). Sales Tax Exemptions, retrieved from http://www.colorado.gov/cs/Satellite/Revenue/REVX/1251570904998

Colorado Revenue (2012). Colorado Sales/Use Tax Rates, retrieved from http://www.colorado.gov/cms/forms/dor-tax/dr1002.pdf

Colorado Revenue (2012). Sales Form, retrieved from http://www.colorado.gov/cs/Satellite?c=Page\&cid=1214992372238\&pagename=Revenu e\%2FREVXLayout 
Colorado Revenue (2012). Sales Tax FYI Publications, retrieved from http://www.colorado.gov/cs/Satellite?c=Page\&childpagename=Revenue\%2FREVXLayo ut\&cid=1193047059515\&pagename=REVXWrapper

Connecticut General Assembly (2011). Chapter 219 Sales and Use Taxes, retrieved from http://www.cga.ct.gov/2011/pub/chap219.htm

Connecticut Revenue (2012). Exemptions from Sales and Use Taxes, retrieved from http://www.ct.gov/drs/cwp/view.asp?a=1477\&q=269920

Connecticut Revenue (2012). Exemption Certificates, retrieved from http://www.ct.gov/drs/cwp/view.asp?a=1477\&q=445816

Florida Library and Information Services (2012). Rule Chapter 12A-1 Sales and Use Tax, retrieved from https://www.flrules.org/gateway/chapterhome.asp?chapter=12A-1

Florida Revenue (2010). Nontaxable Medical Items and General Grocery List, retrieved from http://dor.myflorida.com/dor/forms/2010/dr46nt.pdf

Florida Revenue (2012). Sales and Use Tax, Florida Administrative Code, retrieved from https://taxlaw.state.fl.us/format1.aspx?file=sut_fc\&req=*\&ttype=Sales\%20and\%20Use\% 20 Tax

Florida Revenue (2012). Florida Tax Handbook, retrieved from http://edr.state.fl.us/Content/revenues/reports/tax-handbook/taxhandbook2012.pdf

Georgia Revenue (2011). Georgia Sales and Use Tax Exemptions, retrieved from https://etax.dor.ga.gov/salestax/TLP_2011_List_of_Sales_and_Use_Tax_Exemptions.pdf

Georgia Revenue (2012). Sales and Use Tax Forms, retrieved from https://etax.dor.ga.gov/salestax/st3forms/st3_indx.aspx

Georgia Revenue (2012). Sales and Use Tax Division, retrieved from http://rules.sos.state.ga.us/cgibin/page.cgi?g=DEPARTMENT_OF_REVENUE\%2FSALES_AND_USE_TAX_DIVIS ION\%2Findex.html\&d=1

Idaho Commission (2012). Tax Rates \& Overview, retrieved from http://tax.idaho.gov/i1109.cfm

Idaho Commission (2012). Idaho Sales and Use Tax Administrative Rules, retrieved from http://adminrules.idaho.gov/rules/current/35/0102.pdf

Illinois Revenue (2012). Sales and Use Taxes, retrieved from http://tax.illinois.gov/Businesses/TaxInformation/Sales/rot.htm

Illinois Revenue (2012). Title 86 Part 130 Section 130.120 Nontaxable Transactions, retrieved from http://tax.illinois.gov/legalinformation/regs/part130/130-120.pdf 
Illinois Revenue (2011). Publication 104 Common Sales Tax and E911 Surcharge Exemptions, retrieved from http://tax.illinois.gov/Publications/Pubs/PUB-104.PDF

Indiana Revenue (2012). Income and Sales Tax Information Bulletins, retrieved from http://www.in.gov/dor/3650.htm

Iowa Revenue (2009). Review of Statutory Sales and Use Tax Exemptions, retrieved from http://www.iowa.gov/tax/educate/79120.pdf

Iowa Revenue (2011). Iowa Sales Tax Exemption Certificate, retrieved from http://www.iowa.gov/tax/forms/31014.pdf

Iowa Revenue (2012). Iowa Sales and Use Tax: Taxable Services, retrieved from http://www.iowa.gov/tax/educate/78524.html

Kansas Revenue (2011). Kansas Exemption Certificates, retrieved from http://www.ksrevenue.org/pdf/pub1520.pdf

Kansas Revenue (2011). Sales Tax and Compensating Use Tax, retrieved from http://www.ksrevenue.org/pdf/pub1510.pdf

Kentucky Legislature (2012). Title 103 Finance and Administration Cabinet Department of Revenue, retrieved from http://www.lrc.ky.gov/kar/TITLE103.HTM

Kentucky Legislature (2012). Encouragement of motion picture industry—Legislative purposeDefinitions - Tax credit-Administrative regulations, retrieved from http://www.lrc.ky.gov/KRS/139-00/538.PDF

Kentucky Legislature (2012). Kentucky Revised Statutes, retrieved from http://www.lrc.ky.gov/statrev/frontpg.htm

Kentucky Revenue (2012). Current Year Sales \& Use Tax Forms, retrieved from http://revenue.ky.gov/forms/cursalefrm.htm

Louisiana Revenue (2011). Exemption Table, retrieved from http://rev.louisiana.gov/forms/publications/R-1002\%2808-11\%29.pdf

Louisiana Revenue (2012). Sales Tax, retrieved from

http://rev.louisiana.gov/sections/faq/default.aspx?type=GEN\&cat=SLS\#faq-102

Louisiana Revenue (2012). Sales Tax Forms: 2011, retrieved from http://rev.louisiana.gov/sections/taxforms/default.aspx?code=SLS\&year=2011

Maine Revenue (2011). A Reference Guide to the Sales and Use Tax Law, retrieved from http://www.maine.gov/revenue/salesuse/RefGuideOct2011.pdf

Maine Revenue (2012). Maine Sales Tax Exempt Organizations, retrieved from http://www.maine.gov/revenue/salesuse/exemptions/exemptions.html 
Maine Revenue (2012). Sales Tax Forms, Certificates and Affidavits, retrieved from http://www.maine.gov/revenue/forms/sales/salesforms.htm

Maryland Comptroller (2012). Sales and Use Tax, retrieved from http://business.marylandtaxes.com/taxinfo/salesanduse/default.asp

Maryland Secretary of State (2012). Title 03_Comptroller of the Treasury, retrieved from http://www.dsd.state.md.us/comar/subtitle_chapters/03_Chapters.aspx\#Subtitle06

Massachusetts Laws (2012). Chapter 674H Tax on Retail Sales of Certain Tangible Personal Property, retrieved from http://www.malegislature.gov/Laws/GeneralLaws/PartI/TitleIX/Chapter64H

Massachusetts Revenue (2012). Sales \& Use Tax Forms, retrieved from http://www.mass.gov/dor/forms/trustee/sales-and-use-tax/

Massachusetts Revenue (2012). Uniform Sales \& Use Tax Certificate-Multi jurisdiction, retrieved from http://www.mtc.gov/uploadedFiles/Multistate_Tax_Commission/Resources/Forms/Unifo rm\%20Sales\%20and\%20Use\%20Certificate-12_2011.pdf

Michigan Legislature (2012). General Sales Tax Act (Excerpt) Act 167 of 1933, retrieved from http://legislature.mi.gov/\%28S\%28xatia055pnqrfs555o3ei455\%29\%29/mileg.aspx?page =getObject\&objectName=mcl-205-54a

Michigan Licensing and Regulatory Affairs (2012). State Treasurer-General Sales and Use Tax Rules, retrieved from http://www.state.mi.us/orr/emi/admincode.asp?AdminCode=Single\&Admin_Num=20500001\& $\mathrm{Dpt}=\mathrm{TY} \&$ RngHigh=

Michigan Treasury (2009). Michigan Sales and Use Tax Certificate of Exemption, retrieved from http://www.michigan.gov/documents/taxes/3372_216612_7.pdf

Michigan Treasury (2012). Sales \& Use Tax-List of Topics, retrieved from http://www.michigan.gov/taxes/0,1607,7-238-43529-154427--,00.html

Minnesota Revenue (2012). Sales and Use Tax Instructions Booklet, retrieved from http://www.revenue.state.mn.us/Forms_and_Instructions/sales_tax_booklet.pdf

Minnesota Revenue (2012). Sales and Use Tax Forms and Instructions, retrieved from http://www.revenue.state.mn.us/businesses/sut/Pages/Forms.aspx

Minnesota Reviser of Statutes (2011). Chapter 297a. General Sales and Use Taxes, retrieved from https://www.revisor.mn.gov/statutes/?id=297A

Mississippi Revenue (2012). Sales Tax Exemptions, retrieved from http://www.dor.ms.gov/taxareas/sales/Exemptionssalestax.html 
Mississippi Tax Commission (2012). Part IV Sales and Use Tax, retrieved from http://www.dor.ms.gov/docs/rules_partIV_effective20100201.pdf

Missouri Revenue (2012). Sales Tax Taxability and Exemptions, retrieved from http://dor.mo.gov/faq/business/exempt.php

Missouri Revenue (2012). Sales Tax Holidays, retrieved from http://dor.mo.gov/business/sales/taxholiday/

Missouri Secretary of State (2012). Code of State Regulation Title 12—Department of Revenue, retrieved from http://www.sos.mo.gov/adrules/csr/current/12csr/12csr.asp

Nebraska Revenue (2012). Title 316—Nebraska Department of Revenue Chapter 1 - Sales and Use Tax, retrieved from http://www.revenue.ne.gov/legal/regs/slstaxregs.html\#012

Nevada Legislature (2012). Chapter 372—Sales and Use Taxes, retrieved from http://www.leg.state.nv.us/nrs/NRS-372.html

Nevada Taxation (2012). About Taxes and FAQ'S, retrieved from http://tax.state.nv.us/About\%20taxes\%20and\%20Faqs.html

New Jersey Taxation (2011). Sales Tax Exemption Administration, retrieved from http://www.state.nj.us/treasury/taxation/pdf/pubs/sales/su6.pdf

New Mexico Revenue (2012). Gross Receipts \& Compensating Taxes: An Overview, retrieved from http://www.tax.newmexico.gov/SiteCollectionDocuments/Publications/FYIPublications/FYI105_GROSS\%20RECEIPTS\%20and\%20COMPENSATING\%20TAXES\%20\%20AN\%20OVERVIEW\%202009.pdf

New Mexico Revenue (2012). Gross Receipts Tax Rate Schedule, retrieved from http://www.tax.newmexico.gov/SiteCollectionDocuments/2010grt-trt-jul.pdf

New York Laws (2012). Article 28—Sales and Compensating Use Taxes, retrieved from http://public.leginfo.state.ny.us/LAWSSEAF.cgi?QUERYTYPE=LAWS+\&QUERYDA TA=@LLTAX+\&LIST=LAW+\&BROWSER=BROWSER+\&TOKEN=27020397+\&TA RGET=VIEW

New York Laws (2012). Numerical listing by publication number, retrieved from http://www.tax.ny.gov/pubs_and_bulls/publications/pub_numeric_list.htm

New York Taxation (2012). Sales tax rates and identifying the correct local taxing jurisdiction, retrieved from http://www.tax.ny.gov/bus/st/sales_tax_rates.htm

New York Taxation (2012). Transactions that are not subject to sales tax, retrieved from http://www.tax.ny.gov/bus/st/transactions_not_subject_to_sales_tax.htm 
New York Taxation (2012). Quick Reference Guide for Taxable and Exempt Property and Services, retrieved from

http://www.tax.ny.gov/pubs_and_bulls/tg_bulletins/st/quick_reference_guide_for_taxabl e_and_exempt_property_and_services.htm

North Carolina General Assembly (2012). Article 5. Sales and Use Tax, retrieved from http://www.ncga.state.nc.us/EnactedLegislation/Statutes/HTML/ByArticle/Chapter_105/ Article_5.html

North Carolina Revenue (2012). Sales and Use Tax, retrieved from http://www.dornc.com/taxes/sales/salesanduse.html

North Carolina Revenue (2012). Sales and Use Tax Forms and Certificates, retrieved from http://www.dornc.com/downloads/sales.html

North Carolina Revenue (2012). Sales and Use, Machinery Privilege, Motor Vehicle Lease and Rental, and Additional Sales and Use Taxes, retrieved from http://www.dornc.com/taxes/sales/overview.html

[North Carolina] Streamlined Sales Tax Project (2010). North Carolina State Taxability Matrix, retrieved from http://www.streamlinedsalestax.org/uploads/downloads/State\%20Compliance/North\%20 Carolina/2010/North\%20Carolina\%20Taxability\%20Matrix\%202010.pdf

North Dakota Legislature (2012). Chapter 57-39.2 Sales Tax, retrieved from www.legis.nd.gov/cencode/t57c39-2.pdf

[North Dakota] Streamlined Sales Tax Project (2011). North Dakota State Taxability Matrix, retrieved from http://www.nd.gov/tax/salesanduse/streamlinetax/taxabilitymatrix2011.pdf

North Dakota Tax Commissioner (2012). Sales Tax, retrieved from http://www.nd.gov/tax/salesanduse/

North Dakota Tax Commissioner (2012). Sales \& Use Taxes Frequently Asked Questions, retrieved from http://www.nd.gov/tax/misc/faq/salesanduse/index.html\#su5

North Dakota Tax Commissioner (2012). Sales Tax Exemptions, retrieved from http://www.nd.gov/tax/taxincentives/sales/

Ohio Codes (2012). Chapter 5739: Sales Tax, retrieved from http://codes.ohio.gov/orc/5739

Ohio Taxation (2012). Sales \& Use Tax: Applying the Tax, retrieved from http://tax.ohio.gov/faqs/Sales/sales_taxability.stm\#A02

Ohio Taxation (2012). Sales \& Use Tax Forms—-Results, retrieved from http://dw.ohio.gov/tax/dynamicforms/searchresults_st.asp 
[Oklahoma] Streamlined Sales Tax Project (2011). Oklahoma State Taxability Matrix, retrieved from http://www.streamlinedsalestax.org/uploads/downloads/State\%20Compliance/Oklahoma/ 2011/Oklahoma\%20Taxability\%20Matrix\%202011.pdf

Oklahoma Tax Commission (2011). Oklahoma Sales Tax Exemption Packet, retrieved from http://www.tax.ok.gov/btforms/PktE.pdf

Oklahoma Tax Commission (2011). Oklahoma Sales Vendor Responsibilities—Exempt Sales, retrieved from http://www.tax.ok.gov/btforms/PubD.pdf

Oklahoma Tax Commission (2011). Chapter 65. Sales And Use Tax, retrieved from http://www.tax.ok.gov/rules/rule6511.pdf

Pennsylvania Code (2012). Title 61 Revenue, retrieved from http://www.pacode.com/secure/data/061/061toc.html

Pennsylvania Revenue (2009). Sales and Use Tax Audit Manual, retrieved from http://www.portal.state.pa.us/portal/server.pt/document/635420/sut_audit_manual_pdf?qi $\mathrm{d}=94232470 \& \mathrm{rank}=1$

Pennsylvania Revenue (2012). Sales, Use and Hotel Occupancy Tax, retrieved from http://www.portal.state.pa.us/portal/server.pt/community/sales\%2C_use_hotel_occupa ncy_tax/14487

Pennsylvania Revenue (2012). Sales \& Use Tax Forms, retrieved from http://www.portal.state.pa.us/portal/server.pt/community/sales use_tax/14702

Rhode Island Legislation (2012). Title 44 Taxation, retrieved from http://www.rilin.state.ri.us/Statutes/TITLE44/INDEX.HTM

[Rhode Island] Streamlined Sales Tax Project (2011). Rhode Island State Taxability Matrix, retrieved from http://www.streamlinedsalestax.org/uploads/downloads/State\%20Compliance/Rhode\%20 Island/2011/Rhode\%20Island\%20Taxability\%20Matrix\%202011\%20revised.pdf

Rhode Island Taxation (2004). Synopsis of Rhode Island Tax System, retrieved from http://www.tax.ri.gov/help/synopsis.php\#2

Rhode Island Taxation (2012). Sales \& Use Tax Forms, retrieved from http://www.tax.ri.gov/taxforms/sales_excise/sales_use.php

Rhode Island Taxation (2012). Sales Tax Regulations, retrieved from http://www.tax.ri.gov/regulations/salestax/

South Carolina Legislature (2012). South Carolina Code of Laws Title 12-Taxation, retrieved from http://www.scstatehouse.gov/code/title12.php 
South Carolina Revenue (2012). Sales and Use Tax General Provisions, retrieved from http://www.sctax.org/NR/rdonlyres/8A5BEBBC-7456-40E8-81EF-

9FA9A27ABCDF/0/Chapter72011TaxIncentive.pdf

South Carolina Revenue (2012). Sales and Use Tax Regulations, retrieved from http://www.sctax.org/NR/rdonlyres/359732DB-0889-4171-87D58E2FD0F3C3B3/0/TaxRegulationSalesUseNumericalIndex_forWeb2.pdf

South Carolina Revenue (2012). 2011 Forms \& Instructions: Sales \& Use, retrieved from http://www.sctax.org/Forms+and+Instructions/2011/salesUse/default.htm

South Dakota Revenue (2011). Sales and Use Tax Guide, retrieved from http://www.state.sd.us/drr2/businesstax/publications/st/salestaxguide.pdf

South Dakota Revenue (2012). Sales Tax Publications, retrieved from http://www.state.sd.us/drr2/businesstax/publications/publications.htm

South Dakota Revenue (2012). Sales Tax Forms, retrieved from http://www.state.sd.us/drr2/businesstax/forms/forms.htm

[South Dakota] Streamlined Sales Tax Project (2011). South Dakota State Taxability Matrix, retrieved from http://www.streamlinedsalestax.org/uploads/downloads/State\%20Compliance/South\%20 Dakota/2011/SD11001A01\%20SD\%20Taxability\%20Matrix\%20revised.pdf

[Tennessee] Lexis Nexis (2012). Tennessee Code Unannotated, retrieved from http://www.lexisnexis.com/hottopics/tncode/

Tennessee Revenue (2008). Chapter 1320-5-1 State Sales and Use Tax Rules, retrieved from http://www.State.Tn.Us/Sos/Rules/1320/1320-05/1320-05-01.Pdf

Tennessee Revenue (2011). Sales and Use Tax Guide, retrieved from http://www.tn.gov/revenue/taxguides/salesanduse.pdf

Tennessee Revenue (2012). Sales and Use Tax, retrieved from http://www.tn.gov/revenue/tntaxes/salesanduse.shtml

Tennessee Revenue (2012). Exemption Applications/Certificates, retrieved from http://www.tn.gov/revenue/forms/sales/index.shtml

Texas Comptroller Accounts (2012). Texas Administrative Code Title 34 Public Finance Part 1 Comptroller Of Public Accounts Chapter 3 Tax Administration Subchapter O State Sales And Use Tax, retrieved from http://info.sos.state.tx.us/pls/pub/readtac\$ext.ViewTAC?tac_view=5\&ti=34\&pt=1\&ch=3 \&sch $=\mathrm{O} \& \mathrm{rl}=\mathrm{Y}$

Texas Comptroller Accounts (2012). Texas Sales \& Use Tax Forms, retrieved from http://www.window.state.tx.us/taxinfo/taxforms/01-forms.html 
Texas Comptroller Accounts (2012). Tax Publications, retrieved from http://www.window.state.tx.us/taxinfo/taxpubs/index.html\#sales

Texas Legislature (2012). Tax Code Title 2. State Taxation Subtitle E. Sales, Excise, and Use Taxes Chapter 151. Limited Sales, Excise, And Use Tax Subchapter A. General Provisions, retrieved from http://www.statutes.legis.state.tx.us/Docs/TX/htm/TX.151.htm

Utah Legislature (2012). Utah Code-Title 59-Chapter 12—Sales and Use Tax Act, retrieved from http://le.utah.gov/ code/TITLE59/59_12.htm

[Utah] Streamlined Sales Tax Project (2011). Utah State Taxability Matrix, retrieved from http://www.streamlinedsalestax.org/uploads/downloads/State\%20Compliance/Utah/2011/ Utah\%20Taxability\%20Matrix\%20Revised\%209_9_2011.pdf

Utah Tax Commission (2011). Sales and Use Tax General Information, retrieved from http://tax.utah.gov/forms/pubs/pub-25.pdf

Utah Tax Commission (2012). Rule R865-19S-Sales and Use Tax, retrieved from http://tax.utah.gov/commission/r865-19s

US Census Bureau (2009). Annual Survey of State Government Finances, retrieved from http://www.census.gov/govs/state/historical_data_2009.html

US Census Bureau, Population Division (2009). Annual Estimates of the Resident Population for the United States, Regions, States, and Puerto Rico: April 1, 2000 to July 1, 2009, retrieved from http://www.census.gov/popest/data/historical/2000s/vintage_2009/

[Vermont] Lexis Nexis. 2012. VT Statutes Unannotated, VT Court Rules and VT Constitution, retrieved from http://www.lexisnexis.com/hottopics/vtstatutesconstctrules/.

[Vermont] Streamlined Sales Tax Project (2011). Vermont State Taxability Matrix, retrieved from

http://www.streamlinedsalestax.org/uploads/downloads/State\%20Compliance/Vermont/2 011/Vermont\%20Taxability\%20Matrix\%202011.pdf

Vermont Taxes (2009). Vermont Tax Expenditures 2009 Biennial Report, retrieved from http://www.state.vt.us/tax/pdf.word.excel/statistics/2009/2009\%20Vermont\%20Tax\%20 Expenditure\%20Report\%20REVISED\%201-22-09.pdf

Vermont Taxes (2012). Sales and Use Tax Regulations, retrieved from http://www.state.vt.us/tax/pdf.word.excel/legal/regs/19701.pdf

Vermont Taxes (2012). Forms - 2011/2012 Trust Fund Taxes (Sales and Use, Meals and Rooms, Withholding), retrieved from http://www.state.vt.us/tax/formstrustfund.shtml

Virginia Legislative Information System (2012). Code of Virginia Title 58.1 - Taxation, retrieved from http://lis.virginia.gov/cgi-bin/legp604.exe?000+cod+TOC5801000 
Virginia Taxation (2011). Sales and Use Tax Expenditure Study, retrieved from http://www.tax.virginia.gov/site.cfm?alias=SalesandUseTaxExpenditureStudy

Virginia Taxation (2012). Sales and Use Tax, retrieved from http://www.tax.virginia.gov/site.cfm?alias=SalesUseTax\#Retail

Virginia Taxation (2012). Sales and Use Tax Forms, retrieved from http://www.tax.virginia.gov/forms.cfm?formtype=Sales\%20and\%20Use\%20Tax

Washington Legislature (2012). Chapter 458-20 WAC Excise tax rules, retrieved from http://apps.leg.wa.gov/wac/default.aspx?cite=458-20

Washington Revenue (2012). Retail sales and use tax exemptions, retrieved from http://dor.wa.gov/Content/FindTaxesAndRates/RetailSalesTax/Exemptions.aspx

Washington Revenue (2012). Incentive Programs: Deferrals, Exemptions, and Credits, retrieved from http://dor.wa.gov/content/FindTaxesAndRates/TaxIncentives/IncentivePrograms.aspx

[Washington] Streamlined Sales Tax Project (2011). Washington State Taxability Matrix, retrieved from http://www.streamlinedsalestax.org/uploads/downloads/State\%20Compliance/Washingto n/2011/Washington\%20Taxability\%20Matrix\%20\%202011\%20revised\%2011_2_11.pdf

West Virginia Legislature (2012). West Virginia Code Chapter 11. Taxation, retrieved from http://www.legis.state.wv.us/WVCODE/Code.cfm?chap=11\&art=1

[West Virginia] Streamlined Sales Tax Project (2011). West Virginia State Taxability Matrix, retrieved from http://www.streamlinedsalestax.org/uploads/downloads/State\%20Compliance/West\%20 Virginia/2011/WV11001A01\%20West\%20Virginia\%202011\%20Taxability\%20Matrix\% 20revision\%2008_31_11.pdf

West Virginia Tax Department (2008). Sales and Use Tax Exemptions, retrieved from http://www.state.wv.us/taxrev/taxdoc/tsd300.pdf

West Virginia Tax Department (2012). Food Tax, retrieved from http://www.wva.state.wv.us/wvtax/foodtax.aspx

West Virginia Tax Department (2012). Taxpayer Services Division (TSD) Publications, retrieved from http://www.wva.state.wv.us/wvtax/tsdPublications.aspx

Wisconsin Revenue (2010). Chapter Tax 11 Sales and Use Tax, retrieved from http://docs.legis.wisconsin.gov/code/admin_code/tax/11.pdf

Wisconsin Revenue (2012). Sales and Use Tax Forms, retrieved from http://www.revenue.wi.gov/forms/sales/index.html 
Wisconsin Revenue (2012). Sales and Use Tax Information, retrieved from http://www.revenue.wi.gov/pubs/pb201.pdf

Wisconsin Revenue (2012). Sales and Use Tax Articles, retrieved from http://www.revenue.wi.gov/salesanduse/articles.html

[Wisconsin] Streamlined Sales Tax Project (2011). Wisconsin State Taxability Matrix, retrieved from http://www.streamlinedsalestax.org/uploads/downloads/State\%20Compliance/Wisconsin/ 2011/WI\%20Taxability\%20Matrix\%202011.pdf

Wyoming Revenue (2011). Sales/Use Tax Exemption Guidelines for Purchase or Lease of Manufacturing Machinery and Machine Tools, retrieved from http://revenue.state.wy.us/PortalVBVS/uploads/09Manufacturing\%20Exemption\%20Information.pdf

Wyoming Revenue. 2011. Excise Tax Division Tax Pub. \#1 Agriculture, retrieved from http://revenue.state.wy.us/PortalVBVS/uploads/Publication_AgricultureTax.pdf.

Wyoming Revenue (2012). Chapter 2 Sales and Use Tax, retrieved from http://soswy.state.wy.us/Rules/RULES/6296.pdf

[Wyoming] Streamlined Sales Tax Project (2011). Wyoming State Taxability Matrix, retrieved from http://www.streamlinedsalestax.org/uploads/downloads/State\%20Compliance/Wyoming/ 2011/Wyoming\%20Taxability\%20Matrix\%202011.pdf 
Figure 1. Theoretical Model

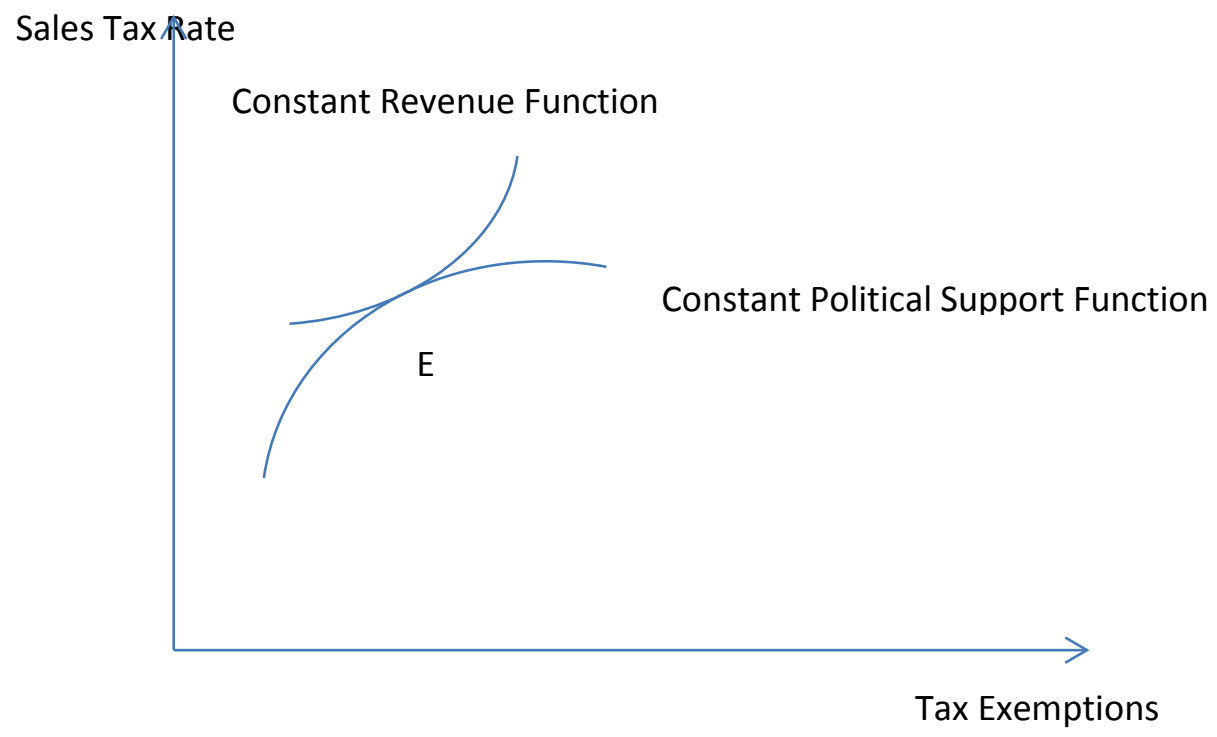


Table 1. Types of Exemptions

\begin{tabular}{|c|c|}
\hline Federal & - Federal preemption principle \\
\hline Transaction & $\begin{array}{l}\text { - Entity-based } \\
\text { - Product-based } \\
\text { - Use-based }\end{array}$ \\
\hline Implementation & $\begin{array}{l}\text { - Automatic (per se) } \\
\text { - Approval-based (certificate of exemption) }\end{array}$ \\
\hline Tax Rate & $\begin{array}{l}\text { - Full } \\
\text { - Partial }\end{array}$ \\
\hline Policy & $\begin{array}{l}\text { - Social } \\
\text { - Intangible } \\
\text { - Too costly to tax } \\
\text { - Sales tax vs. other special taxes }\end{array}$ \\
\hline Special Exemptions & $\begin{array}{l}\text { - Back to School tax holiday } \\
\text { - Energy Star tax holiday }\end{array}$ \\
\hline
\end{tabular}


Table 2. Exemption Categories and Subcategories

\begin{tabular}{|c|c|c|}
\hline Category & Subcategory & Description \\
\hline \multirow[t]{5}{*}{ Food } & Food 1 & Food ingredients \\
\hline & Food 2 & Candy, soda, or bottled water or vending machine transactions \\
\hline & Food 3 & Meals in educational institutions or certain health-care facilities \\
\hline & Food 4 & Other food-related transactions \\
\hline & $\begin{array}{l}\text { Overall } \\
\text { description }\end{array}$ & $\begin{array}{l}\text { Exemptions regarding food ingredients, candy, soda, certain } \\
\text { meals, as well as other transactions involving food items }\end{array}$ \\
\hline \multirow[t]{7}{*}{ Health } & Health 1 & Prescription drugs \\
\hline & Health 2 & Nonprescription drugs \\
\hline & Health 3 & Durable medical equipment \\
\hline & Health 4 & Mobility-enhancing equipment \\
\hline & Health 5 & Dental equipment \\
\hline & Health 6 & Other health-care-related transactions \\
\hline & $\begin{array}{l}\text { Overall } \\
\text { description }\end{array}$ & $\begin{array}{l}\text { Exemptions regarding prescription and nonprescription drugs, } \\
\text { durable medical equipment, mobility-enhancing equipment, } \\
\text { dental equipment, as well as other health-care-related } \\
\text { transactions }\end{array}$ \\
\hline Clothing & None & $\begin{array}{l}\text { Exemptions involving clothing item, accessories, or any clothing- } \\
\text { related items }\end{array}$ \\
\hline \multirow[t]{3}{*}{ Transportation } & Transportation 1 & $\begin{array}{l}\text { New or used vehicles powered by alternative fuel or with low } \\
\text { emissions }\end{array}$ \\
\hline & Transportation 2 & $\begin{array}{l}\text { New or used vehicles (regular fuel), including watercraft, aircraft } \\
\text { and/or railroad stock }\end{array}$ \\
\hline & $\begin{array}{l}\text { Overall } \\
\text { description }\end{array}$ & $\begin{array}{l}\text { Exemptions involving new and/or used vehicles (trailers, } \\
\text { semitrailers, cars), alternative-fuel vehicles, as well watercraft, } \\
\text { aircraft, and related items (parts, etc.). }\end{array}$ \\
\hline \multirow[t]{4}{*}{ Housing } & Housing 1 & New or used homes (mobile, modular) \\
\hline & Housing 2 & Building materials \\
\hline & Housing 3 & Other housing-related transactions \\
\hline & $\begin{array}{l}\text { Overall } \\
\text { description }\end{array}$ & $\begin{array}{l}\text { Exemptions involving new and/or used homes (mobile, modular), } \\
\text { building materials, as well as other housing-related transactions }\end{array}$ \\
\hline $\begin{array}{l}\text { Capital } \\
\text { goods/Industry }\end{array}$ & None & $\begin{array}{l}\text { Exemptions involving machinery, tools, and equipment and parts } \\
\text { used in various industries such as manufacturing, processing, etc. }\end{array}$ \\
\hline Computer & None & $\begin{array}{l}\text { Exemptions involving computer equipment, software } \\
\text { development, digital products, and IT-related services }\end{array}$ \\
\hline \multirow[t]{5}{*}{ Energy/Utilities } & Utilities 1 & Utilities for residential purposes \\
\hline & Utilities 2 & $\begin{array}{l}\text { Utilities for alternative/renewable energy production; alternative } \\
\text { fuels; solar panels, etc. }\end{array}$ \\
\hline & Utilities 3 & Utilities for commercial (industrial) purposes \\
\hline & Utilities 4 & Utilities for agricultural purposes \\
\hline & Utilities 5 & Other utility-related transactions \\
\hline
\end{tabular}




\begin{tabular}{|c|c|c|}
\hline & $\begin{array}{l}\text { Overall } \\
\text { description }\end{array}$ & $\begin{array}{l}\text { Exemptions involving utilities (electricity, water, fuel) for } \\
\text { residential, commercial, and agricultural purposes, as well as } \\
\text { other utility-related transactions }\end{array}$ \\
\hline \multirow[t]{4}{*}{ Farming/Agriculture } & Farming 1 & Farm/agricultural machinery \\
\hline & Farming 2 & Farm/agricultural products (used to feed livestock, etc.) \\
\hline & Farming 3 & Medication for livestock, pest treatments, etc. \\
\hline & $\begin{array}{l}\text { Overall } \\
\text { description }\end{array}$ & $\begin{array}{l}\text { Exemptions involving farm/agricultural machinery, products, } \\
\text { medication, etc. }\end{array}$ \\
\hline Business Incentives & None & $\begin{array}{l}\text { Exemptions involving certain business activities that fall within } \\
\text { certain state economic-development programs }\end{array}$ \\
\hline School-Related & None & $\begin{array}{l}\text { Exemptions involving school-related transactions (charges, } \\
\text { fundraising activities) and other transactions performed by } \\
\text { educational organizations }\end{array}$ \\
\hline Nonprofits & None & $\begin{array}{l}\text { Exemptions involving certain nonprofit organizations. For most } \\
\text { states, the nonprofit status according to the US IRS code [ } 26 \\
\text { U.S.C. } 501 \text { (c)(3)-(7)] does not automatically entitle such } \\
\text { organizations to sales tax exemptions. }\end{array}$ \\
\hline Government-Related & None & $\begin{array}{l}\text { Exemptions involving government agencies and instrumentalities } \\
\text { as well as other publicly owned entities (public utilities, regulatory } \\
\text { commissions, etc.) }\end{array}$ \\
\hline Entertainment & None & $\begin{array}{l}\text { Exemptions involving entertainment-related activities: film } \\
\text { production; selling, renting, or leasing motion picture films; etc. }\end{array}$ \\
\hline Services & None & Exemptions involving certain personal and professional services \\
\hline Tax Holidays & None & $\begin{array}{l}\text { Information about whether or not a state has a sales tax holiday, } \\
\text { as well as details regarding the holiday }\end{array}$ \\
\hline Other & None & $\begin{array}{l}\text { A diverse category of exemptions, ranging from sales of lottery } \\
\text { tickets, bibles, flags, to caskets, zoo animals, packaging materials, } \\
\text { etc. }\end{array}$ \\
\hline
\end{tabular}




\section{Table 3. Descriptive Statistics}

\begin{tabular}{lcccc}
\hline Variable & Mean & Standard deviation & Minimum & Maximum \\
\hline Sales tax (\%) & 5.6 & 1.1 & 2.9 & 7.25 \\
Sales tax revenue per capita (\$) & 777.9 & 254.37 & 421.5 & 1,756 \\
Tax bases & 2.59 & 0.94 & 1 & 5 \\
Exemptions: broad measure & 24.2 & 2.75 & 19 & 31 \\
Exemptions: narrow measure & 11.4 & 1.62 & 7 & 14.5 \\
\hline
\end{tabular}

Note: $\mathrm{N}=44$. AK, DE, HI, MT, NH, and OR excluded. 


\section{Table 4. Summary of Regression Results (Broad Measure)}

Table 4. Summary of Results (Broad Measure)

\begin{tabular}{|c|c|c|c|c|c|c|c|c|}
\hline Dependant Variable & $\begin{array}{l}\text { Sales Tax } \\
\text { Rate (1) }\end{array}$ & $\begin{array}{l}\text { Sales Tax } \\
\text { Rate (2) }\end{array}$ & $\begin{array}{l}\text { Sales Tax } \\
\text { Rate (3) }\end{array}$ & $\begin{array}{l}\text { Sales Tax } \\
\text { Rate (4) }\end{array}$ & $\begin{array}{l}\text { Sales Tax } \\
\text { Rate (5) }\end{array}$ & $\begin{array}{l}\text { Sales Tax } \\
\text { Rate (6) }\end{array}$ & $\begin{array}{l}\text { Sales Tax } \\
\text { Rate (7) }\end{array}$ & $\begin{array}{l}\text { Sales Tax } \\
\text { Rate (8) }\end{array}$ \\
\hline & & & & & \multicolumn{4}{|c|}{ Controlling for local options } \\
\hline Exemptions (Broad) & $\begin{array}{l}0.1055^{* *} \\
(0.0515)\end{array}$ & $\begin{array}{l}0.1469 * * * \\
(0.0512)\end{array}$ & $\begin{array}{l}0.1002 * \\
(0.0556)\end{array}$ & $\begin{array}{l}0.1475 * * \\
(0.0575)\end{array}$ & $\begin{array}{l}0.1084^{* *} \\
(0.0521)\end{array}$ & $\begin{array}{l}0.1523^{* * *} \\
(0.0501)\end{array}$ & $\begin{array}{l}0.1013^{*} \\
(0.0556)\end{array}$ & $\begin{array}{l}0.152^{* *} \\
(0.0561)\end{array}$ \\
\hline Sales Tax Revenue per Capita $\wedge 2$ & $\begin{array}{l}-5.63 \mathrm{e}-06^{* * *} \\
(7.21 \mathrm{e}-07)\end{array}$ & $\begin{array}{l}-5.51 \mathrm{e}-06^{* * *} \\
(7.56 \mathrm{e}-07)\end{array}$ & & & $\begin{array}{l}-5.89 \mathrm{e}-06^{* * *} \\
(7.22 \mathrm{e}-07)\end{array}$ & $\begin{array}{l}-5.83 e-06 * * * \\
(7.43 e-07)\end{array}$ & & \\
\hline Ln(Sales Tax Revenue per Capita) & & & $\begin{array}{l}1.81^{* *} \\
(0.764)\end{array}$ & $\begin{array}{l}1.954^{* *} \\
(0.753)\end{array}$ & & & $\begin{array}{l}1.794 * * \\
(0.776)\end{array}$ & $\begin{array}{l}1.940 * * \\
(0.778)\end{array}$ \\
\hline i_Tax_Base_2 & & $\begin{array}{l}0.784 * * * \\
(0.253)\end{array}$ & & $\begin{array}{l}0.839 * * \\
(0.338)\end{array}$ & & $\begin{array}{l}0.3102 \\
(0.313)\end{array}$ & & $\begin{array}{l}0.608 \\
(0.481)\end{array}$ \\
\hline i_Tax_Base_3 & & $\begin{array}{l}-0.241 \\
(0.282)\end{array}$ & & $\begin{array}{l}-0.257 \\
(0.365)\end{array}$ & & $\begin{array}{l}-0.343 \\
(0.278)\end{array}$ & & $\begin{array}{l}-0.307 \\
(0.364)\end{array}$ \\
\hline i_Tax_Base_4 & & $\begin{array}{l}0.937 * * * \\
(0.245)\end{array}$ & & $\begin{array}{l}1.176^{* * *} \\
(0.348)\end{array}$ & & $\begin{array}{l}0.984^{* * * *} \\
(0.252)\end{array}$ & & $\begin{array}{l}1.209 * * * \\
(0.347)\end{array}$ \\
\hline
\end{tabular}

Note: *indicates p-values less than $0.1 ;{ }^{* *}$ less than $0.05 ; * * *$ less than 0.01 
Figure 2. Partial Regression Plot of Sales Tax and All Exemptions (Broad Measure)

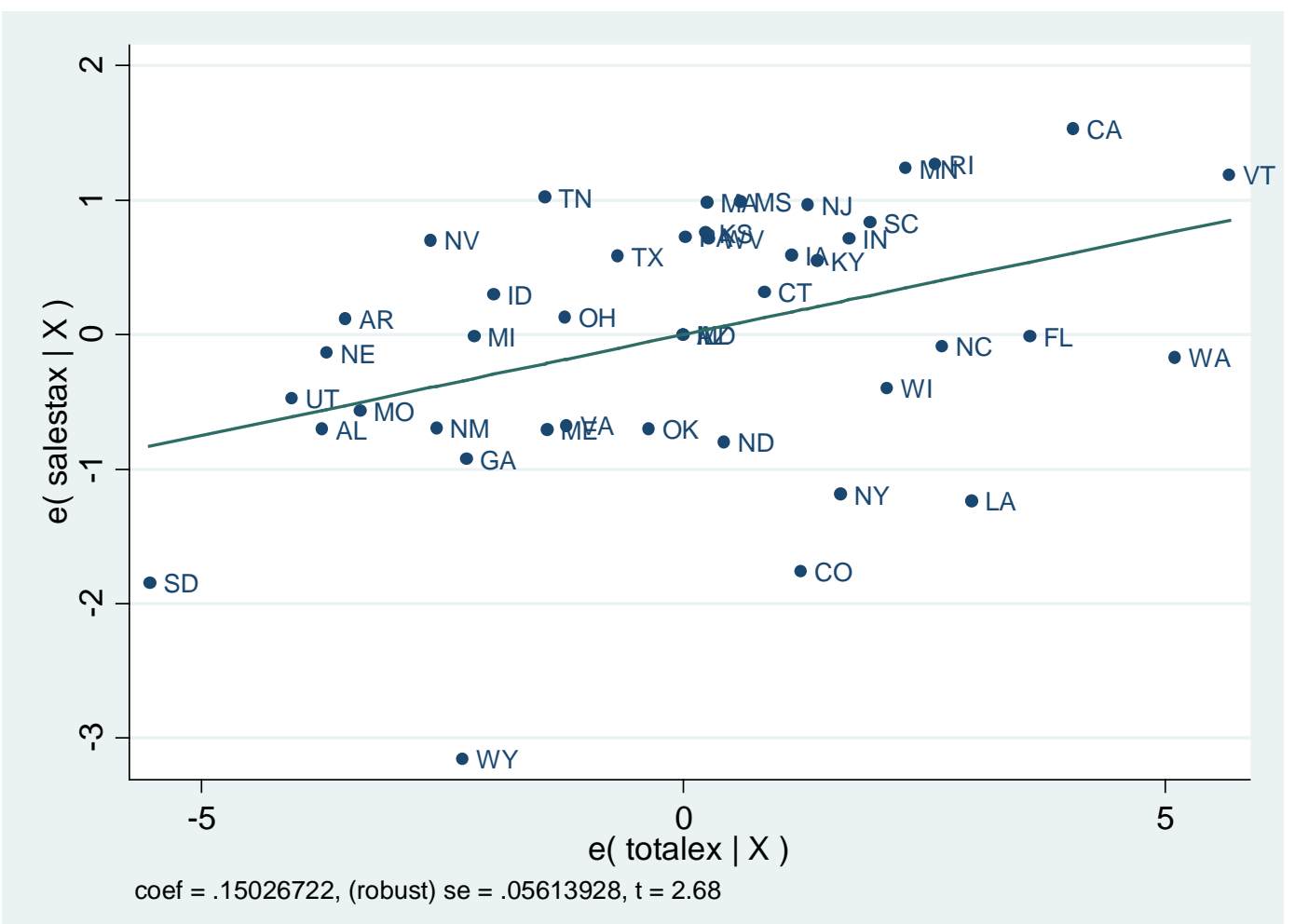

Note: The vertical axis displays the residuals of regressing the sales tax on the independent variables, excluding tax exemptions. The horizontal axis displays the residuals from regression total exemptions on the remaining independent variables. 
Table 5. Summary of Results (Narrow Measure)

Table 5. Summary of Results (Narrow Measure)

\begin{tabular}{|c|c|c|c|c|c|c|c|c|}
\hline Dependant Variable & $\begin{array}{l}\text { Sales Tax } \\
\text { Rate (1) }\end{array}$ & $\begin{array}{l}\text { Sales Tax } \\
\text { Rate (2) }\end{array}$ & $\begin{array}{l}\text { Sales Tax } \\
\text { Rate (3) }\end{array}$ & $\begin{array}{l}\text { Sales Tax } \\
\text { Rate (4) }\end{array}$ & $\begin{array}{l}\text { Sales Tax } \\
\text { Rate (5) }\end{array}$ & $\begin{array}{l}\text { Sales Tax } \\
\text { Rate (6) }\end{array}$ & $\begin{array}{l}\text { Sales Tax } \\
\text { Rate (7) }\end{array}$ & $\begin{array}{l}\text { Sales Tax } \\
\text { Rate (8) }\end{array}$ \\
\hline & & & & & \multicolumn{4}{|c|}{ Controlling for local options } \\
\hline Exemptions (Narrow) & $\begin{array}{l}0.1427 \\
(0.0915)\end{array}$ & $\begin{array}{l}0.2235^{* *} \\
(0.0991)\end{array}$ & $\begin{array}{l}0.1589 \\
(0.1109)\end{array}$ & $\begin{array}{l}0.2545^{* *} \\
(0.1227)\end{array}$ & $\begin{array}{l}0.1469 \\
(0.094)\end{array}$ & $\begin{array}{l}0.2426^{* *} \\
(0.0948)\end{array}$ & $\begin{array}{l}0.1634 \\
(0.114)\end{array}$ & $\begin{array}{l}0.2575^{* *} \\
(0.118)\end{array}$ \\
\hline Sales Tax Revenue per Capita & $\begin{array}{l}0.0121^{* * *} \\
(0.0017)\end{array}$ & $\begin{array}{l}0.0119^{* * *} \\
(0.00189)\end{array}$ & & & $\begin{array}{l}0.0122^{* * *} \\
(0.0017)\end{array}$ & $\begin{array}{l}0.0121^{* * *} \\
(0.0018)\end{array}$ & & \\
\hline Sales Tax Revenue per Capita $\wedge 2$ & $\begin{array}{l}-5.44 \mathrm{e}-06^{* * *} \\
(7.77 \mathrm{e}-07)\end{array}$ & $\begin{array}{l}-5.24 \mathrm{e}-06^{* * *} \\
(8.29 \mathrm{e}-07)\end{array}$ & & & $\begin{array}{l}-5.43 \mathrm{e}-06^{* * *} \\
(7.61 \mathrm{e}-07)\end{array}$ & $\begin{array}{l}-5.22 \mathrm{e}-06^{* * *} \\
(7.94 \mathrm{e}-07)\end{array}$ & & \\
\hline Ln(Sales Tax Revenue per Capita) & & & $\begin{array}{l}1.768^{* *} \\
(0.746)\end{array}$ & $\begin{array}{l}1.898^{* *} \\
(0.717)\end{array}$ & & & $\begin{array}{l}1.880^{* *} \\
(0.741)\end{array}$ & $\begin{array}{l}2.086^{* *} \\
(0.697)\end{array}$ \\
\hline Local_option & & & & & $\begin{array}{l}-0.421^{*} \\
(0.232)\end{array}$ & $\begin{array}{l}-0.580^{* *} \\
(0.252)\end{array}$ & $\begin{array}{l}-0.478^{*} \\
(0.247)\end{array}$ & $\begin{array}{l}-0.662 * * \\
(0.250)\end{array}$ \\
\hline i_Tax_Base_2 & & $\begin{array}{l}0.5401 * * \\
(0.239)\end{array}$ & & $\begin{array}{l}0.5896 * \\
(0.338)\end{array}$ & & $\begin{array}{l}0.0313 \\
(0.290)\end{array}$ & & $\begin{array}{l}0.010 \\
(0.346)\end{array}$ \\
\hline i_Tax_Base_3 & & $\begin{array}{l}-0.2353 \\
(0.280)\end{array}$ & & $\begin{array}{l}-0.264^{* * *} \\
(0.360)\end{array}$ & & $\begin{array}{l}-0.373 \\
(0.273)\end{array}$ & & $\begin{array}{l}-0.422 \\
(0.340)\end{array}$ \\
\hline i_Tax_Base_4 & & $\begin{array}{l}0.8232 * * * \\
(0.249)\end{array}$ & & $\begin{array}{l}1.070^{* * *} \\
(0.356)\end{array}$ & & $\begin{array}{l}0.886 * * * \\
(0.238)\end{array}$ & & $\begin{array}{l}1.129^{* *} \\
(0.332)\end{array}$ \\
\hline i_Tax_Base_5 & & $\begin{array}{l}1.396 * * * \\
(0.484)\end{array}$ & & $\begin{array}{l}1.698^{* *} \\
(0.627)\end{array}$ & & $\begin{array}{l}1.533^{* *} \\
(0.467)\end{array}$ & & $\begin{array}{l}1.838^{* *} \\
(0.601)\end{array}$ \\
\hline $\mathrm{N}$ & 44 & 44 & 44 & 44 & 44 & 44 & 44 & 44 \\
\hline R-Squared & 0.506 & 0.57 & 0.264 & 0.358 & 0.533 & 0.614 & 0.299 & 0.416 \\
\hline
\end{tabular}

Note: *indicates p-values less than $0.1 ; * *$ less than $0.05 ; * * *$ less than 0.01 
Figure 3. Partial Regression Plot of Sales Tax and All Exemptions (Narrow Measure)

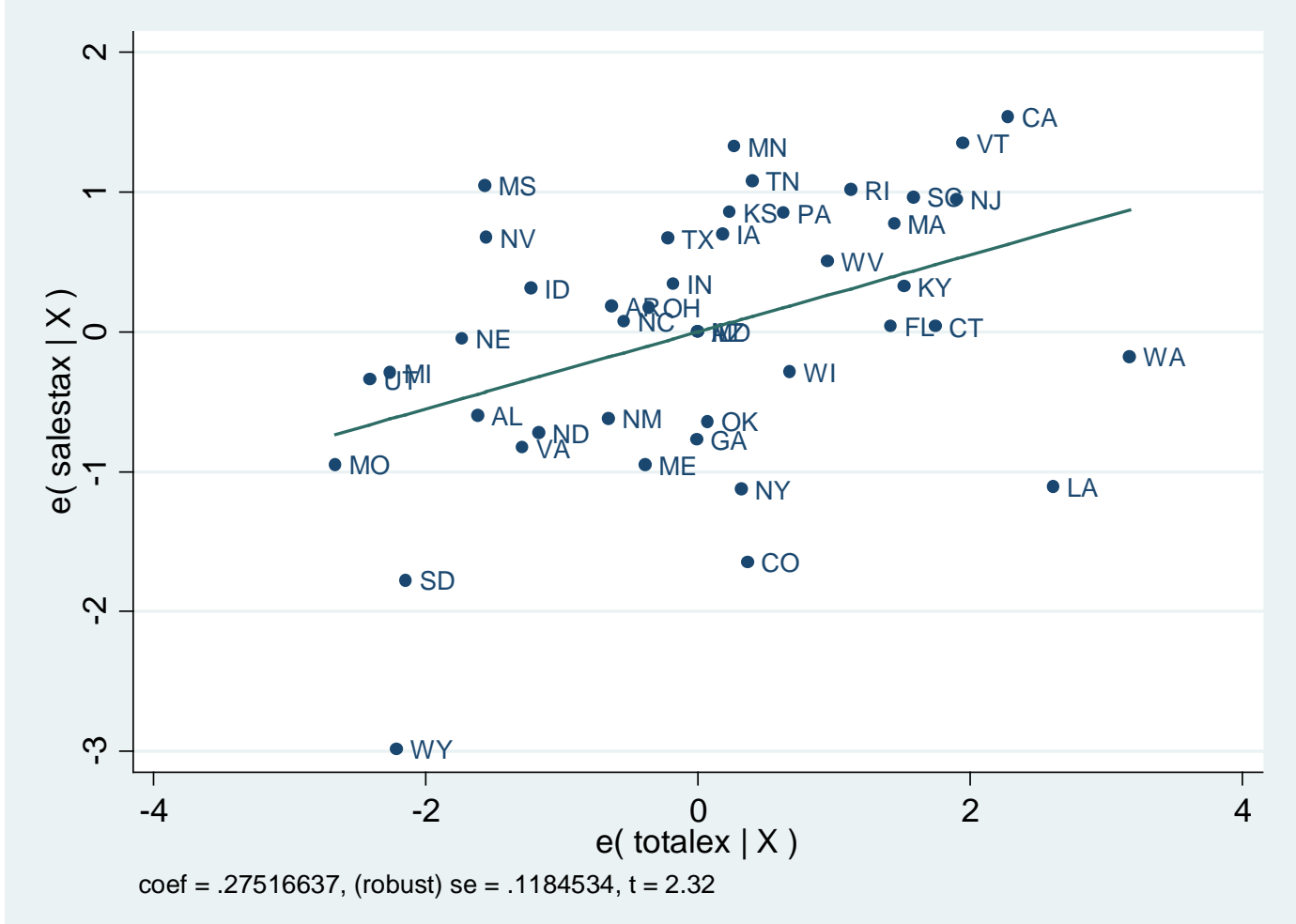

Note: The vertical axis displays the residuals of regressing the sales tax on the independent variables, excluding tax exemptions. The horizontal axis displays the residuals from regression total exemptions on the remaining independent variables. 